\title{
Human trafficking in China
}

\begin{abstract}
It is identified as a source, transit and destination country for human trafficking, issues of human trafficking in China range from forced marriage to forced labor, forced sex work, sale and profitable adoption of babies and human smuggling. Internationally, the illegal, undocumented migrant status of North Korea defectors has made them easy targets for kidnap and abduction, forced sex work, forced marriage and forced labor in factories and agriculture. Although forced labor, forced marriages and forced sex work are significant human trafficking issues in China, the current Chinese laws and campaigns have failed to emphasize these issues. The government should replace the top-down crackdown strategy with a partnership with grassroots organizations and women's groups to help prevent forced labor and identify trafficked victims, while at the same time providing legal redress to the victims of forced labor, forced marriages, forced sex work and the sale of children for the abuse they have endured.
\end{abstract}

Keywords: trafficking, forced labor, forced sex work, human smuggling, china
Volume 3 Issue 2 - 2018

\author{
Tiantian Zheng \\ Professor, Department of Anthropology, State University of \\ New York, USA
}

Correspondence: Tiantian Zheng, Professor, Department of Anthropology, State University of New York, USA, Email zhengt@cortland.edu

Received: February 27, 2018 | Published: March 15, 2018

\section{Introduction}

This article explores issues associated with human trafficking in China, including forced marriages, forced labor, forced sex work, sale of babies and human smuggling. This article will first historicize human trafficking in China. It will then investigate the scope of human trafficking issues in China. It will subsequently explore the policies and strategies of the state to combat human trafficking issues. The article ends with policy recommendations.

\section{The historical evolution of human trafficking in china}

Prior to the establishment of the People's Republic of China in 1949, China had "one of the largest and most comprehensive markets for the exchange of human beings in the world". ${ }^{1}$ From the Han Dynasty (206 BCE-220 CE) to the early twentieth century, a group of "nubi," defined as property to be bought and sold, were legally separate from free people. Less than one percentage of the national population during the Han dynasty, the slaves mostly originated as indentured servants with contracts that stipulated a set amount to pay back to the master in exchange for their freedom. ${ }^{2}$ If the amount was not repaid in three years and if provided a wife by the master, the servant then became a permanent slave. ${ }^{2}$ Slaves were not only sold to families for their needs, but also exported as prostitutes in Britain and laborers in California gold mine in the nineteenth century. While the imperial families owned state slaves who were mainly war captives and criminals, wealthy merchants and land-owners possessed hereditary and purchased slaves. During this time, families at all levels of society relied upon sold people to meet their domestic needs such as disposing of unwanted children, procuring servants and acquiring sexual, reproductive, child-rearing services, leading to an omnipresent market in servants, wives, slaves, concubines, child brides, adopted children and apprentices. ${ }^{1,3-12}$ Indeed, the sale of people was by no means a last resort to counteract the effects of natural disasters and human wars. Instead, it was routinely tolerated, facilitated and actively partaken by family members and community networks as a legitimate solution to family issues and concerns such as worry about daughters' marriage prospects, frustrations with a sick child and fear of diminishing food..$^{8,12}$

Traffickers were often family members, friends, neighbors and lovers, situated in a social milieu that accepted the notion that people could be bought and sold as monetary properties. Household heads, who were the patriarchal decision markers, possessed the authoritarian power to buy and sell their children, concubines, servants, wives and slaves as properties, hence perpetuating the trafficking practice., ${ }^{8,12}$

The market of the sale of people was a response to a shortage of domestic help and reproductive labor. Infanticide and abandonment of females who were perceived as outsiders and non-members of the lineage resulted in a lopsided gender ratio that precipitated the sale of women as concubines, slave girls, servants, infant daughters-in-law, wives, or prostitutes to meet the needs of a surplus of single men. Some women were purchased from market intermediaries, whereas major wives were transferred from one household to another through an exchange of marriage payments called bride price. Males were also bought as either adopted heirs in infancy or hereditary slaves by owners. ${ }^{8,12}$ As mentioned above, such ancient practices were linked to the culturally accepted commodification of people as owned possessions or properties.

For a thousand years, the sale of a child was legalized by a signed receipt that specified the rights of both buyer and seller in the minutest detail. ${ }^{1}$ Though the statutes of the Qing Code (1644-1912) during the Qing (multi-cultural) Empire illegalized various forms of sale of people, it did include provisions that permitted this practice. Families and traffickers regularly appropriated these provisions to argue that impending starvation had forced them to sell their children and that their motivations were charitable, in which cases, they were acquitted by magistrates. ${ }^{8} 12$ During the Republican era (1912-1949) (derived 
from the "Republic of China"), this customary practice was legislated as a new crime during the new legal reform. While the Qing Law glossed over matchmakers, intermediaries and paid witnesses, the Republic law augmented the risk of prosecution and criminalization of sale of people. ${ }^{8,12}$ Despite the criminalization of the sale of people during this era, traffickers were nonetheless able to create innovative strategies to sidestep the legal restrictions and perpetuate the practice. Brokers, matchmakers and other local intermediaries continued supplying families with domestic, reproductive and sexual services through buying and selling people and many local courts advocated leniency. Nearly half of the crime of kidnapping and abduction reported in the newspapers in North China were committed by women criminals. ${ }^{12}$ Indeed, many sales could not have been arranged without the active involvement of women traffickers, who implemented the lure and put the victims at ease. More geographic mobility resulted from urbanization and industrialization during this era also precipitated traffickers to work together to kidnap victims from one place and sell them to another in a different province. The Republican era witnessed an expansion of opportunities, geographic scope of the sale of people and network of traffickers who worked closely together. ${ }^{12}$

The Maoist era (1949-1977) in the People's Republic of China drastically curtailed the practice of human trafficking through the strictly enforced household registration system, the 1950 Marriage Law, closure of brothels, eradication of prostitution and class struggles. The household registration system established in 1958 outlawed mobility and migration through the management of resource distribution. The 1950 Marriage Law outlawed arranged marriages, concubinage and marriage through money or gifts, offering women freedom of marriage and divorce and the right to underage children and inheritance of property. Mobility restriction and resource allocation upon the number of people in a family drastically curtailed trafficking and reduced the need to sell unwanted children. Women's newfound freedom to divorce also exponentially diminished their susceptibility to brokers. Closing brothels, marrying out prostitutes to integrate them into families and waging class struggles between servants and elite families significantly stymied the trafficking practice..$^{13}$ The postMao era (1978-present), however, reignited incentives for traffickers with the one-child policy that resulted in a skewed sex ratio and a shortage of women. The demand for domestic, reproductive and sexual services was conducive to the rise of trafficking. Confiscated and unregistered babies who were born outside of the one-child policy were often sold by family planning officials or traffickers for profits or adoption.

\section{Scope of human trafficking}

Due to a limited official data about the scope of human trafficking in China, analysis has to rely on the "gray" literature and foreign reports from organizations such as NGOS and Human Rights Watch. Identified as a source, transit and destination country for human trafficking, issues of human trafficking in China range from forced marriage to forced labor, forced sex work, sale and profitable adoption of babies and human smuggling. ${ }^{14,15}$ (Figure 1) As shown in the figure above, the total number of young women and children sold in China from 2000-2013 was 92,851 . The number declined from 21,814 in 2000 to 2,500-5,000 between 2003 and 2008, allegedly due to the government crack-down on the trafficking issue. However, despite another national crack-down on trafficking through the Ministry of Public Security in 2009, the number rose to 13,723 sold children and
19,782 sold women from 2009 to 2013 . The true number of cases is believed to be much larger than the officially provided number. The U.S. Department of State most recently downgraded China from the Tier 2 Watch List to Tier 3 - the lowest of the four categories of violators - in the 2017 Trafficking in Persons Report with regard to human trafficking and forced labor. ${ }^{16}$ The report cited the state complicity in forced labor (performed by individuals including Uighur men and women), non-judicial process in the detainment of drug users in drug rehabilitation facilities, the lack of shelters and social service to trafficked victims, the treatment of most forced labor cases as administrative issues rather than criminal prosecutions, the lack of full criminalization of traffickers and the state's forced repatriation of North Koreans. ${ }^{16}$ Prior to the publication of the report, China's Ministry of Foreign Affairs Lu Kang commented on this issue: "The government's determination in fighting human trafficking is unwavering and outcomes are therefore all to see china firmly opposes the US's irresponsible remarks on other countries' fight against human trafficking, based on its domestic laws". ${ }^{17} \mathrm{Lu}$ called on other countries to "jointly" fight this issue. ${ }^{17}$ Despite Lu Kang's accusation that the US applies its own domestic laws to attack other countries, a tier 3 rating could potentially lead to non-trade sanctions and limitations of the US foreign assistance, unless the US president overrules them.

Internationally, because of the dire economic condition in the Democratic People's Republic of Korea, many North Koreans have voluntarily crossed the border to illegally migrate to China searching for a better life. ${ }^{18}$ Their illegal, undocumented migrant status has made them easy targets for kidnap and abduction, forced sex work, forced marriage and forced labor in factories and agriculture. ${ }^{16-20}$ The Chinese government continued forcibly repatriating North Koreans to North Korea where they were subject to severe punishment such as forced labor and execution. ${ }^{16-18}$

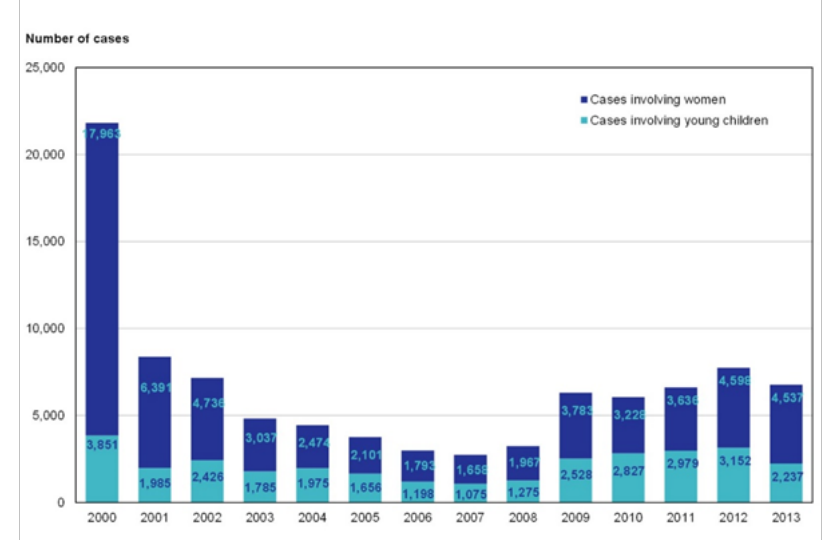

Figure I Number of trafficking cases involving young children and women, 2000-20I3.

\section{Forced marriages}

Kidnapping and abducting women for forced marriages were prevalent prior to the Maoist Communist era (1949-1978) and revived during the post-Mao era (1978-present). Trafficked victims are often aged from 12 to 50 , with a price range of $6,000 \mathrm{RMB}$ to 40,000 RMB $(\$ 1,000$ to $\$ 6,500){ }^{21}$ It is estimated that $90 \%$ of the trafficked victims are from Anhui, Guizhou, Henan, Hunan, Sichuan and Yunnan provinces. They are often sold into forced marriages in underdeveloped areas including Jiangsu, Zhejiang, Shandong, 
Henan and Inner Mongolia which has a lopsided gender ratio and a shortage of women. ${ }^{22,23}$ One of the many resulted social problems is victims' suicide from ingesting chemical pesticides in order to escape the forced marriages..$^{21,24}$ Not only Chinese women and children, but also women from other countries such as Myanmar, Vietnam, Laos, Mongolia, Russia, North Korea as well as countries in Africa and the Americas are at the risk of being sold into forced marriages in China. ${ }^{16,25}$ An estimated 22,000 women have been trafficked from Vietnam into China for forced marriages. ${ }^{26}$ From 2006 to 2010, it is reported that forced marriage accounted for 69.7 percent of 641 trafficking cases in Myanmar and 80 percent of these cases took place in China. ${ }^{25}$ Nyunt Hlaing, Police Colonel of Myanmar's Transnational Crime Department Anti-Trafficking Unit, commented: "China's onechild policy is the main cause of the problem". ${ }^{27}$

As shown, selling and buying women for the purpose of marriage has been a widespread cultural practice in Chinese history. Media coverage between 2007 and 2008 indicated that the source provinces are mainly southwestern regions such as Yunnan and Guizhou and the destination provinces are mainly eastern and central regions such as Fujian, Guangdong, Henan and Shandong where a gender ratio of 119 males for 100 females is more lopsided. ${ }^{28}$ It was reported, for example, that within four months in 2004, 85 women and children were rescued from abduction in Yunnan. Despite the reduced number of cases of kidnapping and sale of women and children, ${ }^{1}, 9$ according to the Ministry of Public Security; it is estimated that each year around 10,000 women and children are sold, mainly in the southwestern regions of China. ${ }^{2}$ These are not only Chinese women, but are also foreign women from the Southeastern, African and American countries such as Vietnam, Laos and Myanmar. ${ }^{29,30}$ Some of the victims migrated to China in search of a better life, only to find themselves deceived and promised with well-paid jobs and subsequently recruited and sold into forced marriages. It was reported that in 2017, 114 women from Myanmar were rescued from forced marriages..$^{31}$ In one case, 17-year-old May Khine Oo, drugged on a train by the water offered by a couple, was subsequently sold twice to forced marriages in China during the next 13 years. She eventually escaped after contacting a student group via the Chinese Wechat messaging service, leaving her two children behind in China. ${ }^{32}$

The harm resulting from the kidnapping, abductions and sale into forced marriages are not only physical, but also emotional, psychological, mental and cultural. Physical traumas include but are not limited to violence, physical abuse, sexual abuse and rape. Emotional, psychological and mental damages can be also severe, deleterious and enduring. Apart from the physical and emotional harm, cultural stigma and shame associated with these women's experiences of sexual violence and forced marriage often lead to their parents' outright rejection of their reintegration into the family after their rescue. ${ }^{29}$ As indicated in the previous section, the demand of women sold into forced marriages is attributed to a range of cultural and economic factors including cultural devalue of women, preference of boys, one-child policy, shortage of women, economic poverty and the high bride price and wedding expense. .,14,19,24 $^{\text {The long-term problem }}$ of the imbalanced gender ratio has reached 117 males for 100 females

${ }^{1}$ The rate has dropped from 2.29 per 100,000 in 1991 to 0.44 per 100,000 in 2002.

${ }^{2}$ It was reported that from 2001 to 2005, 1,794 women and children were sold in a Southwestern prince. ${ }^{33}$ in 2017, an 'improvement' of 119.45 to 100 in $2009 .{ }^{16}$ This lopsided gender ratio has resulted in many unmarried poor men in China's rural areas who are not able to find a wife or are not capable of paying for the bride price or a wedding ceremony. It is reported that in many regions, the bride price is exceeded by the high cost of a wedding ceremony and the gifts for the bride and her natal family. ${ }^{34}$ According to the traditional Chinese cultural values, a daughter is considered an outsider who, after marriage, transfers her allegiance, dedication and labor to her in-law's family. Hence, the birth parents demand a sufficient amount of financial compensation from the bridegroom's family to compensate them for raising the daughter. Unless the man's family pays the desired amount of the bride price and gifts, the parents would not allow their daughter to marry the groom. Socially and economically underprivileged men who are not capable of making this payment find themselves unable to secure an endorsement from the women's parents and hence often left single without a wife.

To resolve the issue and ensure that their lineages be continued through marriage and reproduction of male heirs, many poor men's family members will pool their money in order to be able to purchase a woman from the outside into forced marriages..$^{24}$ In most rural areas in China, it is believed that marriage is essential for producing male heirs and perpetuating male lineage. For single men who are not able to achieve that goal, their purchase of women into forced marriage is often accepted by villagers as morally correct. As a result, often times when the police come to the village and investigates on the issue of forced marriages, villagers would collectively protect the buyers from being detected or discovered. ${ }^{21}$ Often times, it is the young women from socio-economically marginalized, remote regions such as Southwest China who have limited education background who are the target for deception into forced marriages. They are either promised (i.e., deceived) and lured by a well-paying job in a big city, or are sold by their own parents to whoever offers the highest amount of money for marriage for their daughter.

Apart from these cultural and economic reasons, the market economy, population mobility and the neoliberal ideology, which emerged in the 1980s, that glorifies being wealthy since the 1980 s have also contributed to the issue of forced marriage. Population mobility allows women to be sold into forced marriages in remote regions. Deng Xiaoping in the 1980 s proclaimed that "No matter a cat is white or black, as long as it catches the mice, it is a good cat." This neoliberal ideology justifies all means as long as it reaches the end. To the villagers, this ideology legitimizes the sale of women, which is a lucrative business that not only helps boost the local economy, but also resolve the marriage problem and ensure social order. ${ }^{24,35}$

\section{Forced labor}

Forced labor or penal labor often occurs in prison camps and administrative detention facilities. As per the stipulations by the Chinese criminal justice system, reform or reeducation should be accepted through labor by criminals, offenders who have committed minor offenses, drug addicts, sex workers, religious offenders, critics of the government. These people can be issued up to four-year sentences by the police without trial. ${ }^{23}$ In the extensive forced labor camp networks, these inmates manufacture clothing and military uniforms for the domestic market and armed police, as well as consumer goods such as coat linings, silk flowers and Christmas trappings to export to countries such as Europe, the U.S. and South Korea. ${ }^{36,37}$ During labor 
shortages, labor camp officials purchase small-time offenders from other cities with a minimum price of 800 RMB (\$130) for six months of labor. It is reported that in 2012, a 25-year-old woman from Dalian was sold by the police together with a group of 50 young women to another city's forced labor camp during a crackdown on illegal pyramid sales schemes. ${ }^{36}$

Physical abuses include frequent beatings, deprivation of sleepless for days and chained-up position lying in their own excrement without food for weeks. ${ }^{36}$ Under the sub-standard and often extremely harsh working conditions, prisoners are forced to meet a daily quota. Failure to do so will result in solitary confinement or a denial of food rations. Exceeding the quota can sometimes lead to better quality food, though it is said that the energy consumed is not worth the extra food. It is reported that prisoners mine asbestos and other toxic chemicals without protection, handle with batteries and battery acid without hand protection, stand naked in 3-feet chemical liquid intended to tan animal skins and work in facilities with common explosions and other accidents..$^{38,39}$ Although Chinese laws prohibit forced labor, only women and children can be legally recognized as trafficking victims of forced labor and as mentioned above, the Chinese government perpetuates forced labor in state-sponsored drug rehabilitation facilities or administrative detention centers. ${ }^{16}$ Government officials in Xinjiang, for example, coerced ethnic Uighur men and women to engage in forced farm labor in and outside the province. ${ }^{16}$ Even though the law prohibits employers from withholding property from an employee as a security deposit, it is reported that such practice continued, making certain workers vulnerable to forced labor. It is also reported that people with developmental disabilities along with an estimated over 60 million-plus children whose parents had migrated to cities were targeted for forced labor and forced begging (ibid.)

Internationally, many Chinese men were deceived into forced labor in countries such as Mexico, Japan, Australia, the Netherlands, Argentina, European countries, Thailand and Malaysia. ${ }^{30,40}$ Internally, some North Koreans are forced to work in mining, construction and food services. ${ }^{41}$ Some Chinese men, particularly young boys, were also kidnapped or abducted into enslaved forced labor in brick kilns, coal mines and factories. For instance, in 2006, the police uncovered that over 1,000 men were kidnapped or abducted and then forced to make bricks without any payment in hundreds of brick kilns in Shanxi Province. ${ }^{42}$ It was reported that hundreds of these forced laborers were teenagers and children who were abducted and then compelled to work in inhumane conditions. ${ }^{42}$

It was reported that local officials were complicit in selling the children into forced labor and child labor through working with these illegal factories. ${ }^{42}$ It is the collusion of these local officials with the illegal abductors and kidnappers that have impeded the progress of helping the children's parents locate the lost children and track down these illegal, remote facilities that engaged in forced labor. The physical, emotional and psychological harm inflicted upon these children were so severe that many of the children, upon rescue, were not able to express any emotions.

\section{Forced sex work}

During World War II, the Japanese military force abducted, kidnapped and coaxed up to 200,000 women, mostly Chinese and Korean, to work as sex slaves or "comfort women" for the Japanese army. ${ }^{13,43}$ Comfort women were forced to work in occupied areas in China, where the Japanese military set up brothels in 20 to 30 counties in Manchuria. ${ }^{43}$ Comfort women were used by the Japanese army camp as sex slaves performing like sexual machines. ${ }^{13}$ The comfort women's system was implemented to prevent venereal disease in the Japanese army and to guarantee security of the occupied area. ${ }^{13}$ The existing trafficking literature and Chinese anti-trafficking law classify all women in prostitution as trafficked victims due to the definition of prostitution as sexual exploitation. ${ }^{9,14,19,24}$ The rationale is that no women with free will and free choice would choose to engage in sex work as sex work fundamentally violates women's human rights, reduces women to sexual objects and humiliates women. Thus, there is no record of women who are sold or abducted into sex work, as the law fails to separate voluntary from involuntary sex workers. The existing trafficking literature and Chinese anti-trafficking law lump all sex workers as "trafficked," despite of the fact that there was little or no evidence that they have entered sex work through force.

Internationally, it was reported that women from North Korea, Vietnam, Burma, Mongolia, Malaysia, the Philippines and Thailand have migrated to China to work as prostitutes. ${ }^{2,16}$ It was also reported, however, that Chinese women have travelled abroad to such countries as: Taiwan, Hong Kong, most Southeast Asian countries for prostitution. ${ }^{15}$ Extensive research of Chinese sex workers in ten cities in Asia and the U.S. shows that there is no overarching national or international organized crime group that is involved in the transnational sex trade and that most of the sex workers were not recruited, but voluntarily pursued the process of going overseas to work as sex workers. ${ }^{44}$ Internally, the relaxation of the household registration system has allowed rural women to migrate to the city for prostitution. ${ }^{13,45}$ However, the state's policy and strategies to combat sex trafficking denies women's agency and choices to work as sex workers, deprives voluntary sex workers of work and creates the potential for exploitation and violence in their working environment. ${ }^{13,45}$

\section{Sale of babies}

It is estimated that annually some 200,000 children are sold to couples abroad through adoption. ${ }^{30}$ Decades of one-child policy and the preference for male children resulted in not only forced marriages to meet the needs of a surplus of single men, but also the sale of outof-plan babies to avoid law enforcement. Not only some families with out-of-plan children sell the children for unofficial adoption, but also some family planning officials have been accused of selling confiscated babies. Orphanages have been caught buying babies and reinventing their origins. Ranmeier ${ }^{12}$ reports that across China children born out of quota are vulnerable to sale for profitable adoption. ${ }^{12}$

\section{Human smuggling}

Research has shown that undocumented, illegal Chinese migrants abroad had sought out traffickers or "snakeheads" as their helpful facilitators to help them migrate out of China for a better living and a new livelihood. ${ }^{46}$ Contrary to common beliefs, these snakeheads are not mafia figures, but friends of friends, neighbors, or even family members. ${ }^{46}$ Research has shown that sponsors, who are the relatives and friends of the migrants, will pay off their debts as soon as, or shortly after, the migrants arrive in the destination country. ${ }^{47,48}$ In addition, some local officials also contract with snakeheads to smuggle 
their own family members out of China for a discounted price. ${ }^{47,48}$

The stringent criteria for legitimate immigration can only be met by the educated, the skilled, the wealthy and the ones who have already had family members abroad. ${ }^{49}$ Those with low socioeconomic means who do not have foreign ties have virtually no means to fulfill these demands of the family reunification program, points system, the business and entrepreneur recruitment programs and or the refugee determination system. ${ }^{49}$ For these people, the only way to overcome these legal hurdles against their international migration to work overseas is to try to find traffickers who can help them achieve their goal. In their view, it is the immigration laws and immigration officials who deport them and who are the greatest threat to their mobility and pursuit of a new life. ${ }^{49}$ In essence, the traffickers are the facilitators who can help them overcome or by-pass the restrictions of their mobility and transform their illegal status. ${ }^{3}$

Interviews with smugglers who travel through Mexico and Central America into the U.S. reveal that Chinese migrants, upon entry into the U.S., are instructed by their smugglers to claim that they are either fleeing persecution due to China's one-child policy or fleeing China's religious repression. ${ }^{47}$ In so doing, they successfully avoid immediate deportation through seeking political or religious asylum in the US To further facilitate the 'legitimacy' of their claims, lawyers hired by snakeheads represent them, in exchange for a fee, to help them obtain asylum and permanent residency.

\section{Response mechanisms: policies and strategies}

There is no shortage of laws against human trafficking and human smuggling in China. These laws include the first criminal Law in 1979, the 1984 Criminal Law, the 1987 Regulations, the 1991 Decision on Strictly Forbidding the Selling and Buying of Sex, the 1991 Decision on Severe Punishment of Criminals Who Abduct and Traffic in or Kidnap Women and Children, the 1992 Law on Protecting the Rights and Interests of Women (Women's Law), the Revised Criminal Law of 1997 and the 1999 Entertainment Regulations. The laws stipulate severe penalties for traffickers and smugglers. For example, Article 240 of the Fifth Session of the Eighth National People's Congress specifies that "those abducting and trafficking women or children are to be sentenced to 5 to 10 years in prison plus fine" ${ }^{50}$ Furthermore, in December 2009, the Chinese government ratified the UN Trafficking in Persons Protocol, bringing the domestic laws on par with international standards within 24-months.

In November 2013, the Chinese government modified the onechild policy to allow single-child parents to have a second child. As we have seen in the previous sections, the demand for forced marriage, forced sex work, forced labor and sale and profitable adoption of babies is inexorably linked to the one-child policy and the shortage of women. This policy change can potentially mitigate issues of forced marriage, forced sex work, forced labor and sale and profitable adoption of babies. Despite the comprehensive and strict laws against trafficking and smuggling, implementation of the law has been severely undermined by corruption of government officials As noted above and elsewhere, in many cases, government officials, including the police, have colluded with smugglers and traffickers and impeded the successful implementation of laws and regulations. ${ }^{47,51,52}$

To further conflate the efforts to combat trafficking and slavery, China's anti-trafficking laws equate trafficking with prostitution and ignore other forms of trafficking such as forced labor and forced marriages. The laws deem prostitution a form of violence against ${ }^{3}$ For corporations that unknowingly work with smugglers and traffickers. ${ }^{57,58,59}$ women and hence, as a form of trafficking. Since the 1980s when consumption venues such as nightclubs mushroomed, China has published a number of laws to ban prostitution and the third party's involvement in prostitution. ${ }^{53}$ Rooted in this policy is the conviction that no free women would voluntarily choose prostitution which not only commodities and humiliates women, but also robs women of their human rights. ${ }^{49}$ According to these laws, a person's consent to sex work is irrelevant and anyone's facilitation of a person's entry into sex work is penalized as committing the trafficking crime. ${ }^{49,53}$ The law subjects organizers or facilitators to severe criminal punishment and punishes the entertainment industry and hotels for failing to prohibit prostitution. ${ }^{54}$ While the law criminalizes third party involvement in prostitution, it prescribes mandatory educational detention to rescue and educate those who sell sex. As Gil et al..$^{55}$ state, the minister in Shenzhen admitted, "a large number of prostitutes, once completing their compulsory education at reformatories [sic], go straight 'back on the game," "and "although many are repatriated [sic], more are coming [into the city]." In essence, the laws fail to address the intractable social issues such as income inequality, rural-urban disparity and lack of job opportunities. ${ }^{56}$ Because the Chinese state conflate trafficking with prostitution and perceive migrants for prostitution as trafficked victims, in combating trafficking, the state has mainly targeted prostitution and disregarded other forms of trafficking such as forced labor and forced marriages. Such a campaign to addresses trafficking for the purpose of prostitution and illegal migration embodies the state's anti-prostitution stance and border control goals. ${ }^{49}$

In response to the proliferation of consumption venues such as nightclubs, since 1989, the Chinese government has launched a series of crackdowns called anti-vice campaigns on a number of "vices," including trafficking of women, prostitution, pornography, gambling and drugs. ${ }^{13}$ Crackdowns continue to be employed today to enforce policies against prostitution. However, despite any appearance of trying to address the problem, the illegalization of prostitution, the reeducation detention and deportation of sex workers have failed to thwart the sex industry or forced sex work.

As researchers have argued elsewhere, ${ }^{13,24}$ many police and local government officials appropriate the crackdown campaigns as a means to extort handsome briberies from "offenders" such as the proprietors of entertainment industries. "Offenders" who regularly submit a considerable sum of bribery to the local police or government officials are informed of the time, date and place of these crackdowns ahead of time so that they can be prepared for it. The offender either takes refuge in the countryside or goes underground during the crackdown period to escape the arrest and the harsh penalty during the crackdowns. They will not resume their activities until the crackdown period ends. Hence, these crackdowns exert little impact on the trafficking in women as they are essentially invisible or go underground during the perilous periods. ${ }^{13,24}$

In many ways, it is the mobility control that is behind the fight of trafficking of women. Since 2010, the government has worked with Southeast Asian governments such as Thailand and Vietnam to enforce border control and deport smuggled Southeast Asian women back to their countries. ${ }^{60}$ Harnessing the bilateral energy from the Chinese and Southeast Asian governments to combat the trafficking of women, the Chinese government is able to procure support and help to deport illegal immigrants from these countries into China. Border control is simultaneously attained in the name of fighting against the trafficking of women. Similarly, North Korean migrant women, upon discovery by Chinese authorities, are identified as trafficked victims and deported back to North Korea. ${ }^{18,20}$ It is seldom if ever 
taken into consideration whether they have voluntarily migrated into China, or have already established a family in China. It is reported that in Jilin Province, in the very north-eastern corner of China, where, for example, even though some North Korean women had already been married to Chinese men with children, neither the women nor their children are protected by the Chinese government. In fact, their children are stripped of legal rights and access to any formal education in China. ${ }^{20}$ In these situations, the Chinese government forcefully repatriate and deport the women back to North Korea. Once returned to North Korea, they risk being tortured, subjected to harsh penalty, or even death for having deflected from North Korea. Calling these North Korean women "trafficked victims in need of rescue" and deporting them back to North Korea evinces the state's concern of border control under the mask of concern for trafficking of women.

As such, the state's specific concerns about prostitution and border control have led the anti-trafficking campaigns to exclusively focus on prostitution as "the sexual exploitation of women," failing to address the issues of forced labor, forced marriages and forced sex work..$^{14,15}$ People who have been sold into forced labor, forced marriages and forced sex work receive little or no assistance. Deportation of women back to North Korea, or detention centers, fail to offer them any protection, but only subject them to further marginalization and possible abuse. ${ }^{18}$ Therefore, North Korean women, after deportation, are confronted with severe punishment and even death for their escape, rural migrant women who work as voluntary sex workers would likely suffer physical abuse and mistreatment in the detention center. The policy has not only failed to protect victims, but also enhanced their vulnerability to physical abuse in detention centers.

\section{Policy recommendations and conclusion}

Based on the evidence presented in this article, the following suggestions and recommendations are made to the current state policy.

I. The Chinese laws and campaigns should distinguish the difference between trafficking and prostitution and establish systematic procedures to identify victims of forced labor, forced marriages and forced sex work and provide comprehensive victim protection services and social support to both internal and foreign victims throughout the country. Forced labor, forced marriages and forced sex work are significant human trafficking issues in China, yet the current Chinese laws and campaigns have failed to emphasize these issues. Rather, they have devoted almost all the energy to police raids of the entertainment establishments, punishment of all sex workers and border and movement control. ${ }^{13,49}$ Because of police raids of the entertainment places and punishment of all sex workers, women are either forced to the detention centers where they can fall prey to sexual assaults by the police or are forced to go underground and work in a more dangerous environment.

II. The government should replace the top-down crackdown strategy with a partnership with grassroots organizations and women's groups to help prevent forced labor and identify trafficked victims. Crackdown campaigns in entertainment places have fueled corruption and removed voluntary sex workers who can potentially assist the law enforcements in identifying true victims of trafficking. ${ }^{13,49}$ In excluding the communities that they purport to assist; the campaigns fail to create alliances with grassroots communities and organizations to access their expertise and forge successful interventions to tackle the trafficking issues. The government should work in collaboration with these grassroots organizations to identify and rescue the true victims of trafficking and preclude and combat forced labor.
III. For foreign victims from countries such as North Korea, the government should cease deporting and repatriating them back to their source countries where they would be faced with severe persecution, punishment, or even death. Instead, the government should provide legal alternatives such as temporary or permanent residence permits to the victims of foreign trafficking. The government should link its policy with the United Nation's 4Ps - prevention, protection, prosecution and partnerships to fight against trafficking.

IV. The government should provide legal redress to the victims of forced labor, forced marriages, forced sex work and the sale of children for the abuse they have endured. Research has demonstrated that victims often experience physical diseases and psychological distress and trauma. ${ }^{61-64}$ Legal proceedings should be in process to ensure that the perpetrators prosecuted and penalized for their crimes. To protect the victims from the perpetrators' future threats or revenge, the government should provide a wide range of protection services including job training, shelter, social welfare, education and medical, mental and legal services to ensure the victims' successful reintegration into their families, communities and society. In addition, a policy of mass education and public awareness should be implemented.

V. The Chinese government reported that only 18 of 2,300 government shelters were dedicated to Chinese and foreign victims of trafficking ${ }^{16}$ and much social service are currently provided by non-government agencies, which is neither consistent nor reliable.

VI. Last but not the least, the government should terminate institutionalized forced labor in state-sponsored drug rehabilitation facilities and administrative detention centers. ${ }^{16}$

VII. Given the massive scale of human trafficking from forced marriage to forced labor, forced sex work, sale and profitable adoption of babies and human smuggling, the likelihood of the Chinese government making significant progress and implementing large-scale policy changes remains small. The political, social and economic factors that have been fueling these crimes are too strong, while the government's crackdown practices have been too weak. The fragrant gender gap, officials' complicity, pressure of economic prosperity, deportation of North Koreans and conflation of prostitution with trafficking have in many ways been conducive to the perpetuation of forced marriage, forced labor, forced sex work, sale and profitable adoption of babies and human smuggling. The government should replace the top-down crackdown strategy with a partnership with grassroots organizations and communities in an alliance to address and ameliorate these pressing issues.

\section{Acknowledgements}

None.

\section{Conflict of interest}

Author declares that there is no conflict of interest.

\section{References}

1. James WL. Transaction in People: The Chinese Market in Slaves, Servants, and Heirs. In: Watson JL, editor. Asian and African Systems of Slavery. Berkeley and Los Angeles: University of California Press; 1980. p. 223-250.

2. T'ung tsu C. Law and Society in Traditional China. Paris: Mouton \& Co. 1961. 304 p. 
3. James WL. Chattel Slavery in Chinese Peasant Society: A Comparative Analysis. Ethnology. 1976;15(4):361-375.

4. Marinus MJ. Slavery at the End of the Qing Dynasty. In: Cohen JA, editor. Essays on China's Legal Tradition. Princeton: Princeton University Press; 1980. p. 348-352.

5. Jerry D. Marriage, Adoption, and Charity in the Development of Lineages in Wu-his from Sung to Ch'ing. In: Ebrey P, Watson RS editors. Kinship Organization in Late Imperial China 1000-1940. Berkeley and Los Angeles: University of California Press; 1986. p. 170-209.

6. Susan M. Grooming a Daughter for Marriage: Brides and Wives in the Mid-Ch'ing Period. In: Watson RS, Ebrey P, editors. Marriage and Inequality in Chinese Society. Berkeley and Los Angeles: University of California Press; 1991. p. 204-230.

7. Maria J. Concubines and Bondservants: The Social History of a Chinese Custom. London: Zed Books; 1988.

8. Rubie WS. Wives, Concubines and Maids: Servitude and Kinship in the Hong Kong Region, 1900-1940. In: Watson, Patricia E, editors. Marriage and Inequality in Chinese Society., Berkeley and Los Angeles: University of California Press, 1991. p. 231-255.

9. Lu H, Liu J, Crowther A. Female Criminal Victimization and Criminal Justice Response in China. British Journal of Criminology. 2006;46(59):859-874.

10. Baohua H. Concubinage and Servitude in Late Imperial China. London: Lexington Books. 2015

11. Matthew SH. Polyandry and Wife-Selling in Qing China: Survival Strategies and Judicial Interventions. Berkeley and Los Angeles: University of California Press; 2015.

12. Johanna RS. Sold People: Traffickers and Family Life in North China. Cambridge: Harvard University Press; 2017.

13. Tiantian Z. Red Lights: The Lives of Sex Workers in Postsocialis China. Minneapolis: University of Minnesota Press; 2009.

14. Catherine HM. Enforcing the U.S. Trafficking Victims Protection Act in Emerging Markets: The Challenge of Affecting Change in India and China. Cornell International Law Journal. 2010;43(1):173-206.

15. Robyn E, Laidler KJ, Petersen CJ. Trafficking of Mainland Chinese Women into Hong Kong's Sex Industry: Problems of Identification and Response. Asia Pacific Journal on Human Rights and the Law. 2007;2:35-84

16. US Department of State. Trafficking in Persons Report 2017. Office to Monitor and Combat Trafficking in Persons. US Department of State; 2017.

17. James G, Koran L. "US Lists China as among Worst Human Trafficking Offenders.” CNN Politics. 2017 June 27.

18. Tiantian Z. "Transnational Migration, Global Links and Social Inequality: Human Trafficking and North Korean Women in China.' The International Journal of Interdisciplinary Global Studies. 2015;10(1):1-4.

19. Mark PL. Human Trafficking in China. The DISAM Journal 2008;40-41.

20. Tin W. China: Trafficking of North Korean Women. Womens International Network News. 2003;187:57.

21. David E. Burma's Women Forced to be Chinese Brides. The Telegraph. 2011 September. 4.

22. Yik Yi C. Human Trafficking and Smuggling in China. Journal of Contemporary China. 2011;20(68):39-52.
23. Christie E, Tiefenbrun S. Gendercide and the Cultural Context of Sex Trafficking in China. Fordham International Law Journal. 2008;32(3):731-780.

24. Ming ZG. Trafficking of Women for Marriage in China: Policy and Practice. Criminology and Criminal Justice. 2003;(1):83-102.

25. Madeline F. Sex Trafficking and China's One Child Policy. The Diplomat. 2014 November. 6.

26. Katie C. Taking the Journey Together: A United Response to Trafficking in the Mekong Region. World Vision Asia-Pacific Communications; 2006.

27. Metro. The Burmese Brides Trafficked into China to Marry Tota Strangers. Metro. 2013

28. Jiang F. SIREN Human Trafficking data Sheet. United Nations InterAgency Project on Human Trafficking: Phase III. 2008.

29. Hill G. Buying Brides in China - Again. Anthropology Today. 1996;12(4):29-41.

30. Michelle L. Human Trafficking in China. Human Trafficking Search. 2014.

31. Coconuts Y. 102 Human Trafficking Victims Rescued from China in First Six Months of 2017. Coconuts Yangon. 2017.

32. South China Morning Post. This Myanmar Woman Escaped a Life of Forced Marriages in China, and Left Two Children Behind. South China Morning Post. 2017.

33. Xinhuanet. Yunnan Public Security Agencies (China) Rescued Over 2,000 Trafficked Women and Children Over Last Five Years. 2005

34. Sarah B. Kidnapping and Selling Women and Children: The State's Construction and Response. Violence against Women. 1999;5(12):1437-68.

35. Ping Z. An Introduction. The Development of Women and Women's Studies in China Since 1949. Regina: Social Policy Research Unit: University of Regina; 1999.

36. Andrew J. Behind Cry for Help from China Labor Camp. New York Times. 2013 June 11

37. Michael W. "China Expels Al Jazeera Channel." The New York Times. 2012

38. Michael C. Chinese Slaves Make Goods for American Malls. Human Events. 1997;53(25):4.

39. Antonella M. "The Chinese Concentration Camps No One is Talking About." Panam Post. 2017.

40. Peter K. China's Human Traffickers. The Nation. 1994;17:422-5.

41. Carol M. State Department reprimands China over sex trafficking and forced labor. The Washington Post. 2017.

42. Howard F. Reports of Forced Labor Unsettle China. The New York Times. 2007;16:3

43. Ryan L. Revealed: The Chinese Documents 'Proving' that Japan's Occupying Army Forced Asian Women to Work as Sex Slaves.' Daily Mail. 2014

44. Kolin C, Finckenauer J. Selling Sex Overseas: Chinese Women and the Realities of Prostitution and Global Sex Trafficking. New York: New York University Press; 2012.

45. Tiantian Z. Ethnographies of Prostitution in Contemporary China: Gender Relations, HIV/AIDS and Nationalism. New York: Palgrave Macmillan; 2009.

46. Sheldon Z. Chinese Human Smuggling Organizations. Stanford 
California: Standard University Press; 2008.

47. Cleo KJ. Supporting the Snakeheads: Human Smuggling from China and the 1996 Amendment to the U.S. Statutory Definition of 'Refugee'. The Journal of Criminal Law \& Criminology. 2000;90(4):1271-1316.

48. Kolin C. Smuggled Chinese: Clandestine Immigration to the United States. Philadelphia: Temple University Press; 1999.

49. Tiantian Z. Sex-Trafficking, Human Rights, and Social Justice. Routledge; 2010.

50. Fifth Session of the Eighth National People's Congress. Law of the People's Republic of China on the Protection of Rights and Interests of Women. Order of the Chairman of the People's Republic of China. 1992. No. 58.

51. Young CS. Modelling for Determinants of Human Trafficking. Discussion Papers, Ibero America Institute for Economic Research. $2012 ; 216$

52. Ethan K. The New Global Slave Trade. Foreign Affairs. 2006;85(6):103-115.

53. Elaine J. China, Sex and Prostitution. London and New York: Rouledge Curzon; 2004.

54. Zhang H. Female Sex Sellers and Public Policy in the People's Republic of China. In: Jeffreys E editor. Sex and Sexuality in China. New York: Routledge; 2006.

55. Vincent G, Wang M, Anderson A, et al. Plum Blossoms and Pleasant: Prostitutes, Prostitution, and Social Control Measures in Contemporary China. International Journal of Offender Therapy and Comparative Criminology. 1994;38(4):319-337.
56. Tiantian Z. "Consumption, Body Image, and Rural-Urban Apartheid in Contemporary China." City and Society. 2003;15(2):143-163.

57. Katherine S, Martin H, Smith M. "Human Trafficking: A Global Multi-Billion Dollar Criminal Industry." International Journal of Public Law and Policy. 2014;4(3):293-308.

58. Katherine S, Betts T. Your Company May Unwittingly Be Conducting Business with Human Traffickers: How Can You Prevent This? Business Horizons. 2015;58:225-234.

59. Stefan L, Martin H, Smith K, et al. A Descriptive Analysis of Ethics Codes, CSR, and Efforts to Combat Human Trafficking. International Journal of Corporate Governance. 2014;5(3/4):156-177.

60. Xueying Q. Bianmin Kua Bianjing Guaimai Funv Fanzui Huodong Yanjiu (A Study of the Sale of Women Across Borders). New Findings in Theory. 2014;11(32):34-39.

61. Alexander B. U.S. Exposure to Forced Labor Exports from China. US-China Economic and Security Review Commission: Staff Research Report. 2017.

62. Maria J, Miers S. Women and Chinese Patriarchy: Submnission, Servitude and Escape. Hong Kong: Hong Kong University Press; 1994.

63. Angela S. Slaves and Forms of Slavery in Late Imperial China. Slavery and Abolition. 2003;24(2):143-154.

64. Kevin X. The 'Missing Girls' from China: Reforms Are Too Little Too Late. Harvard International Review. 2014;36(2):33-36. 